\title{
Consumer Behavior within the Covid-19 Pandemic A Systematic Review
}

\author{
Perera K.J.T.*, Fernando P.I.N., Ratnayake R.M.C.S., Udawaththa U.D.I.C. \\ Department of Management Sciences, Faculty of Management,_Uva Wellassa University, Sri Lanka \\ *Corresponding Author
}

\begin{abstract}
COVID-19 spreads globally with a unique makeup and high intensity. During this global pandemic, addressing "consumer behavior" could send signals to the industrial sector, and it is worthwhile to identify the hidden antecedents of consumer behavior during the pandemic. The study's main purpose is to organize and standardize current knowledge on pandemic hoarding behavior. The methodology section is followed by the analysis and discussion portion, which comprises a) citation analysis, which was done to analyze developing research publications on consumer behavior during a pandemic, and b) comprehensive analytical models within the literature. Research papers were selected from well-known research databases such as Web of Science, J Store, and Google Scholar, and the analysis included 43 research papers. The research consist with two sections: (a) citation analysis and (b) identifying comprehensive analytical models. The citation analysis revealed three major themes: (1) panic buying behavior during pandemics, (2) new trends in pandemic buying, and (3) online buying behavior during pandemics. Furthermore, review propose Ling \& Ho (2020) model be aligned to fill a need in consumer behavior research. Moreover, findings reveal a unique perspective on government policymaking that will aid in improving the effectiveness of governments' existing lockdown policy measures by governing and controlling individuals' behaviors and attitudes, allowing for a more holistic and integrated response to the pandemic.
\end{abstract}

Keywords: Consumer Behavior, COVID-19 Pandemic, Marketing, Online Buying, Panic Buying

\section{INTRODUCTION}

$\mathrm{F}$ rom the dawn of civilization to the present day, humans have adapted to a plethora of "conditions or changes," some of which are caused by natural disasters and others that are induced purposely. Throughout this long voyage, humans will encounter tragic circumstances that have not been addressed previously via various stages of development, which are referred to as pandemics (Fernández et al., 2020). The impulsive disaster spreads the first half of the year 2020 around the world by creating gigantic destruction to the life of human beings. It was initially identified as Corona Virus, and later, it was titled Corona Virus Disease-19 or COVID-19 (Qiu et al., 2020). Accordingly, the virus was formed first in Wuhan city, Hubei province of China P.R., later spread its wings around the world by creating massive devastation to the existence and the economic well-being of the human. Since the medications were incompetent to establish the treatment for the disease, several public health procedures have been implemented as a preventive action, particularly social distance among people while the virus scattered hastily (Fong et al., 2020).

According to the Stephany et al. (2020), the level of consequence that the COVID-19 pandemic has generated is dissimilar from one country to another country based on the health structure of the country, economic firmness and flexibility, the immunity of the public, the government policies and protection ability of the population. Starting in late 2019, continued throughout the year 2020 by exhibiting a first and second wave until the dawn of 2021, this novel Corona Virus could be considered as the most critical-lifethreatening challenge to mankind in Twenty-First Century. The hazardous misadventure was able to drastically adjust the lifestyle of the people and the business environment (Ho et al., 2020). Industries like Trade, Agriculture, Tourism, Transportation, and activities of the business environment are extremely destructed by the COVID-19 based on the stability and deficiency in investment enforced to decrease the level of workforce in a long-run perspective (Patel et al., 2016). Once the Covid-19 pandemic was declared by the World Health Organization (WHO), most countries applied social distance as a preventive step, and it is ranged based on the situation of the lockdown country. Based on the prevailing situation, people are restricted from participating in large-scale social meetings while the restaurants and hotels are temporarily closed. Further, some economic sectors have received the freedom to function in small constraints, and householders are highly advised on social distancing and staying at home. Interestingly, most employees are communicated to "work from home" through an online platform and reduce social connections with people due to the nature of the virus spreading (Andersen et al., 2020).

Among all, addressing the "consumer behavior" during this pandemic around the globe might provide signals to the industrial sector. The consumers' purchasing decision is grounded on the intrinsic and the extrinsic individualities (Asioli et al., 2017, Richardson et al., 1994), and alteration in day-to-day existence creates variation in outmoded customer behavior. The consumer is mentally stressed in an unstable economic, social and political environment context, and they feel that they cannot adjust to environmental changes (Botti \& McGill, 2011). Consumers' pressure pushes themselves to save money superfluously for acquiring necessary items, and thereby customers demonstrate the needless comportment on 
gathering substances (Durante \& Laran, 2016). Some scholars termed this as "unnecessary stockpiling behavior."

According to Arora et al.(2020), consumer behavior is affected mainly in five ways during the COVID- 19 period as such; (i) shift to value and essentials: most householders shift to purchase essential goods and spend less on optional types of products (ii) flight to digital and channel: online transactions are promoted, and customers easily order online the goods or services they required and easily purchase the product (iii) shock to loyalty: even though some customers loyal to a particular brand, under the low product availability, the brand-loyalty have diminished and opted for an available product in the market (iv) health and "caring" economy: customers tend to purchase healthy products rather than cosmetic items in previous. This trend has created an avenue for multinational companies to offer healthy packages based on the extraordinary demand in the marketplace (v) homebody economy: consumers stay-at-home while spending time with regular home duties by reducing their shopping and traveling, and socializing. Hence these five main trends were drastically affected to the novel way of consumer behavior or as a novel strategy at NEW NORMAL.

\section{Research gap and significance}

Different scholars are addressing the COVID-19 pandemic from different perspectives. Consumer behavior is one of the main elements in marketing and business. A massive economic downturn is observable among the economies due to the destructive behavior of the pandemic. Therefore, many researchers focused on consumer buying behavior in several industries, products, and countries as an essential field to promote businesses that collapsed in the pandemic situation. However, previous studies mainly focus on a specific area, development, or industry concerning consumer buying behavior. This paper attempts to comprehensively review the research articles to provide an insight on consumers' buyer behavior during the Covid-19 pandemic, and techniques they are adopting in day-to-day life from the perspective of different countries and industries.

\section{Research objective}

Aligned with this requisite, the principal objective of this paper is to systemize and organize the contemporary knowledge on consumer behavior during the Covid-19 pandemic, which would be enormously valuable for future researchers. We have conducted a systematic literature review to achieve the research objective. The approach led us to observe the diverse models based on disasters. Further, the article attempts to weave through the maze of literature available about consumer behavior during a crisis compared to the regular. The rest of this paper is organized as follows: First, the methodology is extensively discussed; second, analysis and discussion sections are presented where we present our: a) citation analysis, which was performed to evaluate the emerging research studies of consumer behavior and, b) comprehensive analytical models within the literature. Last, we present our conclusions.

\section{METHODOLOGY}

This scholarly work adopted a systematic approach to identify and review the relevant literature. The authors conduct the systematic search from November-2020 to January 2021, during the second wave of the COVID-19. Within the context, 269 research articles were downloaded from the well-reputed databases, including Web of Science, JStore, and Google Scholar. Covering the central theme of consumer behavior during a covid-19 pandemic, many other search strings were developed depending on the purpose of this study. The searches were not limited by time. Downloaded articles were screened with three steps; first, articles were screened depending on their title and keywords to filter inappropriate articles. 62 articles were removed in the first step; second, in-depth reading of the research papers' abstracts was filtered out 115 inappropriate articles. Finally, the researcher analyzes the full paper of each article to filter out unnecessary research papers. At the end of the three steps, 43 research papers were used for the analysis, whereas a limited number of scholarly work is available catering to the areas of the "consumer behavior" and "COVID-19 pandemic".

\section{ANALYSIS AND DISCUSSION}

The analysis was twofold: a) citation analysis and main themes identified within the research context, and b) comprehensive analytical models within the existing literature caters to consumer behavior during the COVID-19 pandemic.

\section{Citation analysis and themes developed}

This analysis aimed to identify the most influential papers with the themes in the respective study. After the comprehensive evaluation, 43 research papers were determined and developed the themes by the authors. Herein, Table 1 classifies the identified research papers into diverse three clusters based on their content similarities with the objectives of this study. Further, the identified themes would be way forward for future research areas, mainly to conduct an empirical analysis on consumer behavior. Identified three themes will be the foundation for future research based on empirical data with the second pandemic wave to the worldwide economie.

Table 01: Citations Analysis and Themes developed

\begin{tabular}{|c|c|c|c|}
\hline Themes & Authors & $\begin{array}{c}\text { Published } \\
\text { Year }\end{array}$ & Citations \\
\hline \multirow{4}{*}{$\begin{array}{c}\text { Panic Buying } \\
\text { Behaviour }\end{array}$} & Hall, M. C.,et al & 2020 & 137 \\
\cline { 2 - 4 } & Addo, P. C., et al & 2020 & 118 \\
\cline { 2 - 4 } & Loxton, M., et al & 2020 & 105 \\
\cline { 2 - 4 } & Arafat, S. Y.,et al & 2020 & 23 \\
\cline { 2 - 4 } & Prentice, C., et al & 2020 & 66 \\
\hline
\end{tabular}




\begin{tabular}{|c|c|c|c|}
\hline & Islam, T., et al & 2021 & 90 \\
\hline & Arafat, S. Y.,et al & 2020 & 74 \\
\hline & $\begin{array}{c}\text { Kuruppu, G. N., \& De } \\
\text { Zoysa, A }\end{array}$ & 2020 & 7 \\
\hline & Asioli, D.,et al & 2017 & 74 \\
\hline & $\begin{array}{l}\text { Richardson, P. S., Dick, } \\
\text { A. S., \& Jain, A.K }\end{array}$ & 2016 & 1754 \\
\hline & $\begin{array}{c}\text { Organization for } \\
\text { Economic Co-Operation } \\
\text { And Development } \\
(\text { Oecd })\end{array}$ & 2020 & 383 \\
\hline & Botti, S., \& Mcgill, A. L. & 2011 & 309 \\
\hline & $\begin{array}{l}\text { Durante, K. M., \& Laran, } \\
\text { J. }\end{array}$ & 2016 & 91 \\
\hline & Keane \& Neal & 2021 & 73 \\
\hline & $\begin{array}{l}\text { Perry, R.W., Lindell, } \\
\text { M.K }\end{array}$ & 2003 & 274 \\
\hline \multirow{13}{*}{$\begin{array}{l}\text { New Trends in } \\
\text { Consumer } \\
\text { Behaviour }\end{array}$} & $\begin{array}{c}\text { Mehta, S., Saxena, T., \& } \\
\text { Purohit, N. }\end{array}$ & 2020 & 93 \\
\hline & Arora, N.,Et Al & 2020 & 28 \\
\hline & Amalia & 2012 & 10 \\
\hline & Hoon Ang, S.,Et Al & 2001 & 888 \\
\hline & $\begin{array}{c}\text { Fernández-Villaverde, J., } \\
\text { \& Jones, C. I. }\end{array}$ & 2020 & 164 \\
\hline & $\begin{array}{l}\text { Qiu, Y., Chen, X., \& Shi, } \\
\text { W. }\end{array}$ & 2020 & 327 \\
\hline & Fong, M. W., Et Al & 2020 & 56 \\
\hline & $\begin{array}{c}\text { Ho, J., Hui, D., Kim, A., } \\
\text { \& Zhang, Y. }\end{array}$ & 2020 & 8 \\
\hline & Patel, V., Et Al & 2016 & 65 \\
\hline & $\begin{array}{c}\text { Juranek, S., \& Zoutman, } \\
\text { F. }\end{array}$ & 2020 & 22 \\
\hline & Stephany, F., Et Al & 2020 & 45 \\
\hline & Andersen, M., Et Al & 2020 & 26 \\
\hline & $\begin{array}{l}\text { Flatters, P., \& Willmott, } \\
\text { M. }\end{array}$ & 2009 & 319 \\
\hline \multirow{8}{*}{$\begin{array}{l}\text { Online Buying } \\
\text { Behaviour }\end{array}$} & $\begin{array}{c}\text { Van Den Poel, D., \& } \\
\text { Buckinx, W. }\end{array}$ & 2005 & 364 \\
\hline & Pantano, E.,Et Al & 2020 & 199 \\
\hline & $\begin{array}{l}\text { Rebecca Hodge \& Scott } \\
\text { Jeffrey }\end{array}$ & 2007 & 233 \\
\hline & Kim, Rae Yule & 2020 & 126 \\
\hline & Bounie, D.,Et Al & 2020 & 47 \\
\hline & Bhatti, A., Et Al & 2020 & 126 \\
\hline & $\begin{array}{c}\text { Gao, X., Shi, X., Guo, } \\
\text { H., \& Liu, Y. } \\
\end{array}$ & 2020 & 48 \\
\hline & Nguyen, H. V., Et Al & 2020 & 47 \\
\hline
\end{tabular}

\begin{tabular}{|c|c|c|c|}
\cline { 2 - 4 } & $\begin{array}{c}\text { Suresh, A. S., \& Biswas, } \\
\text { A. }\end{array}$ & 2020 & 10 \\
\cline { 2 - 4 } & Ozturk, R. & 2020 & 4 \\
\hline Ali, B. & 2020 & 64 \\
\cline { 2 - 4 } & Veeragandham, M.,Et Al & 2020 & 6 \\
\hline & Thakur, C.,Et Al & 2020 & 1 \\
\hline & Kaur, P. & 2020 & 0 \\
\hline & $\begin{array}{c}\text { Amichai-Hamburger, Y., } \\
\text { Wainapel, G., \& Fox, S. }\end{array}$ & 2002 & 785 \\
\hline
\end{tabular}

Source: Citation analysis and themes

Given the citation analysis, the authors performed the analysis based on the most cited research papers and the latest research papers related to COVID-19. Many scholarly articles are based on the topic, whereas altogether, 45 research papers were cleared out. From the citation analysis, we discovered three main themes, namely: (1) Panic Buying Behavior, (2) New Trends in consumer behavior, and (3) Online Buying Behavior.

Interestingly, some research themes are more prominent than others; for instance, more citations for Theme 1 focus on the Panic buying behavior during the pandemic. Further, social media and online buying behavior-related scholarly work have been identified as an emerging discipline, where some of the empirical research studies were observed focusing on the panic buying behavior of the consumers. This was highlighted during the first-second waves of the pandemic in some countries, later nick-named "Toilet paper panic buying." We have not found such studies within the Sri Lankan context, whereas identified as an empirical research gap within the Consumer behavior in a Pandemic. Further, we explored that scholarly work based on Panic buying behavior (Theme 1) and Online buying behavior (theme 3 ) have been popular compared with other themes, whereas empirical studies based on the Asian context, especially China, the origin for the COVID-19, is intensively common which are targeted the Asian consumer behavior. However, citation records demonstrate all three Themes are much influential and trending with the booming of the pandemic.

As authors, we thematically analyzed the scholarly work to evaluate the comprehensive analytical models focusing on consumer behavior. In the contrary, some scholars linked consumer behavior with natural disasters, and the more recent researchers concentrate on the COVID-19. The analytical models are categorized based on the identified three themes, and at last, a conceptual model has been proposed.

\section{Panic buying in the covid-19 pandemic}

Panic buying is an evolving tendency that has been noticed in the aftermath of a pandemic but is not confined to it. Based on expert judgment, a large percentage of panic 
buying behavior-related literature from developing nations has been uncovered, covering the reasons and impact of panic buying (Arafat et al., 2020). According to Oxford (2020), panic buying is the act of acquiring huge quantities of goods or services due to sudden fears of a shortage or price increase. Panic buying is a typical market response to natural and artificial disasters, and it frequently occurs when buyers anticipate or respond to a crisis. Panic buying is an evolving tendency that has been noticed in the aftermath of a pandemic but is not confined to it. Based on expert judgment, a large percentage of panic buying behavior-related literature from developing nations has been uncovered, covering the reasons and impact of panic buying (Arafat et al., 2020). According to Oxford (2020), panic buying is the act of acquiring vast quantities of goods or services due to sudden fears of a shortage or price increase. Panic buying is a common market response to natural and artificial disasters, and it frequently occurs when buyers anticipate or respond to a crisis. Those demanded goods have no direct link to COVID-19 or lockdown protection (Kuruppu \& De Zoysa, 2020). As a result, due to the importance of internet media outlets, the reasoning behind panic buying during the COVID-19 crisis is significantly more difficult to evaluate. In recent years, social media and mainstream media have significantly influenced people's perceptions of the world and themselves. As a result, these aspects function as a significant force that affects people's conduct, particularly during a crisis (Kuruppu \& De Zoysa, 2020).

Consumers are more likely to store commodities and other important things that they believe will help them get through the crisis and anticipate supply shortages. Some people may simply be concerned about a huge price increase resulting from the accident (Su, 2010). Previous research has looked into several components and theories to understand the reasons and behaviors of panic buying behavior in customers. Since the lockout, panic buying has increased, and social distancing measures were intensified in mid-March 2020. Panic buying and hoarding started in early March 2020 and peaked at the end of the month, when the lockout was extended, and social isolation became more severe (Prentice et al., 2020).

There are several misconceptions about the phenomenon of impulse buying. One plausible explanation for emergency buying is to reduce the expense of out-of-pocket supplies during crises and pandemics. Panic buying was a natural human reaction to imminent catastrophes and emergencies, either rationally or irrationally, in an attempt to defend and retake control of panic (Leung et al., 2021).

COVID-19-related government measures are linked to panic buying, according to the findings of the semantic study. In January and February 2020, when these interventions had a smaller scope, Australian customers went about their normal buying and consumption routines (Prentice et al., 2020). People in the COVID-19 situation stocked up on preventive disease products and rushed to stock up on basic home items with no warning of a scarcity. The use of social media to propagate panic purchasing information was crucial (Islam et al., 2021). People with high emotionality and conscientiousness ratings are more likely to have experienced paranoia and anxiety due to Covid-19, which can lead to panic buying.

Furthermore, the social media site encouraged users to distribute information about potential supply shortages. Those still apprehensive about COVID-19 put their trust in specific social media posts and began acting like stored commodities. This condition may have been avoided if city authorities had done a better job with public relations, ensuring that residents had low perceptions of threat and anxiety, causing them to change their panic buying habits (Hall et al., 2020).

\section{New trends in consumer behavior}

People are not all the same, and not everyone has the same perspective on a situation that has bad consequences, such as an economic or other crisis (Amalia et al., 2012). Personality traits may also attenuate these changes in consumption behavior due to an economic crisis (Ang et al., 2001). These personality traits are consumers' risk aversion, value consciousness, and materialistic tendencies. Earlier research suggested that in times of crisis, consumers' behavior shifts, resulting in a considerable change in utility patterns (Mehta et al., 2020).

Researchers also discovered a few new tendencies during the crisis, such as demand simplification due to limited options during the crisis, which persists post-crisis, where individuals buy simpler goods with high value (Flatters \& Willmott, 2009). According to Mehta (2020), even the wealthy voiced displeasure with excessive consumerism after the crisis and focused on recycling and teaching their children traditional and straightforward values.

The impact of the recession on consumer attitudes and patterns is significant, according to Flatters and Willmott (2009). The recession has accelerated some developments while slowing or stopping others entirely. Consumers prefer easy, value-oriented products and services that simplify their lives, as well as a focus on the enactment of a corporation where consumers are angered by unlawful action and unethical company behavior. The authors were interested in learning more about customer behavior during COVID-19 because of the shift in consumer behavior during times of crisis (Mehta et al., 2020).

\section{Market dynamics during covid-19}

This pandemic has a severe impact on the nation's economies hinting towards change in market dynamics. An online survey conducted by Bostan Consultancy Group in five countries (China, Italy, France, the UK, and the US) found different spending changes. Accordingly, many consumers anticipate saving more and spending less on discretionary items such as fashion, luxury goods, toys and games and signs 
of growing interest in preventive health care and household cleaning supplies categories that are likely seeing an additional slight bump in spending as a result of the virus (Lara et al., 2020). Consumers replaced restricted activities with increased digital engagement, at-home activities, and health and sanitation practices during lockdowns. McKinsey report (2020) also shows similar findings to the Bostan Consultancy Group survey. A few months into COVID-19, consumer shopping online has increased significantly across many categories, especially in the essentials and homeentertainment categories.

Interestingly, this habit will continue even after the COVID-19 crisis (Abe, 2020). Pantano et al. (2020) found that consumers reacted favorably as retailers sought ways to meet customers' desires by online shopping. COVID-19 has been related to increased online spending in other reports (e.g., Nguyen et al. 2020; Kim 2020; Bounie, Youssouf and John 2020). Despite a decline in net revenue, they largely accept that internet shopping has improved. COVID-19, on the other hand, has not been related to a decrease in online shopping (Ali, 2020). Further, consumer sentiment and category spending in relation to COVID-19 explores many differences across age groups and many similarities and opportunities for companies to engage with consumers in key categories. Across markets, younger generations including generation $\mathrm{Z}$ and millennials, express less optimism and worry than more mature generations and plan to make spending trade-offs across many more categories than the older. Interestingly, the elderly are more likely to maintain the spending. They have accumulated more wealth on average to use in weathering a crisis and already tend to spend more on average (Lara et al., 2020).

Moreover, Abe (2020) highlights high-income earners and millennials are leading the way in shifting spending online across both essential and nonessential items. The COVID-19 Barometer (2020) report points out different behavior among Indian consumers and explores six distinct consumer segments, defined by levels of worry, information consumption, adherence to rules, and government trust (Kantar., 2020). During the previous outbreaks such as SARS, MERS, and other natural disasters, consumers displayed economic elastic behavior in the form of rapid, steady, or slow market recovery. A part of this behavior is permanent and brings in structural changes in the way we live, work and make buying decisions (KMPG, 2020).

\section{Comprehensive analytical models}

With the previous research work, we analyzed comprehensive analytical models developed by several scholars relating to consumer behavior during this COVID-19 pandemic (Fernando et al., 2021). And we consider the models developed recently by scholars who directly relate to the current study. Among all models, we identified the model proposed by Ling \& Ho (2020) from the viewpoint of social behaviors from a social dilemma perspective.
According to Ling \& Ho (2020), most individuals' fear, uncertainty, greed, self-interest, and opportunistic (defective/unethical) behaviors triumph over the collective interest during the pandemic. Individuals' non-cooperative behavior causes hassles, dissatisfaction, and other negative externalities and encourages others to act selfishly. Individuals' behavioral responses are linked to social dilemma theories and ideas, focusing on conscious or unconscious selfinterest and opportunistic conduct. These sociological factors are critical in answering the issues of what and why people act the way they do during the coronavirus epidemic. According to the model, (a) fear, (b) uncertainty, and (c) greed cause selfinterest behavior then lead to panic buying. Hence this model would be proposed by authors to test empirically during the COVID-19 in diverse country perspectives to understand how consumers behave with the fear of pandemic. Figure 1 illustrates the model proposed by Ling \& Ho, (2020).

Figure 01: Effects of the Coronavirus (COVID-19) Pandemic on Social Behaviors: From a Social Dilemma Perspective
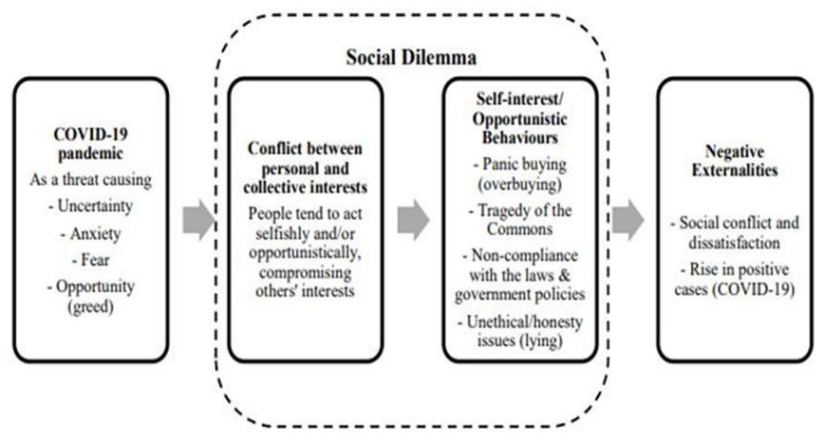

Source: (Ling \& Ho, 2020).

\section{CONCLUSION}

Based on the literature review, most consumer behavior research revealed panic buying trends, new consumer behavior trends, and online buying behavior themes. Further, individuals' emotionality, social media and mass media involvement, government intervention, and information dissemination become more powerful aspects that stimulate customers buying behavior in the COVID 19 era. Demand simplification of rich people, more concern towards value-oriented products and services, dissatisfaction with excess consumption, and focus on recycling and teaching their children traditional and straightforward values are the prominent trends that led authors' interest to explore consumer behavior during COVID-19. Consumers have started to trust the internet, online shopping during the COVID-19. As a result, global e-commerce patterns and global online shopping have increased. Grounded on the numerous scholars' investigation, this has a severe impression on economies intimidating towards change in market dynamics to diverse spending patterns, various usage of available facilities in different age groups, and income levels.Moreover, consumers' spending pattern is divergent in these three waves of COVID - 19. An empirical investigation of the local consumer 
environment is needed to uncover the true and hidden motivations for stockpiling behavior. We propose the model developed by Ling \& Ho (2020) as a conceptual framework to further illustrations. Therefore, researchers can use this model to measure consumer behavior through the social aspect. We suggest that using qualitative approaches to further studies will benefit society in the pandemic situations in more practical markets with this model.

In most nations, the COVID-19 epidemic has considerably impacted modifying consumer behavior. Retailers are encouraged to adapt to the changes by using technology to adjust their business strategies. This thorough review may open up new possibilities for retailers and marketers to comprehend the diverse and dynamic ways in which consumers behave, including the retail distribution pattern. However, consumer behavior cannot be generalized due to cultural and environmental differences. As a result, additional research is continually needed to keep up with the changing behavior of consumers. Given the pandemic's unknown trajectory, consumer behavior across stages is a dynamic mix of old and new habits, highlighting culture and operations and fully aligning with digital transformation projects. Hence, the review and systematization of the literature have resulted in significant suggestions for businesses and organizations. First and foremost, companies must incorporate rapid digital change into their operations. For example, social media's importance in society had already grown before to the COVID-19 problem, but it has now been amplified. Moreover, firms and businesses must address consumers' perceptions of risk.

\section{Limitations of the study}

Despite the fact that the article search was conducted in the different databases, which provides a good balance of quality and coverage, there are still some drawbacks to this study. Numerous publications were not included in the analysed databases, which could imply that their quality is variable. However, in order to systematize the literature in an acceptable length of time, this decision was necessary to limit the databases.

\section{ACKNOWLEDGEMENT}

The research was fully funded by the Uva Wellassa University of Sri Lanka with grant No. UWU/RG/ST/2021/014

\section{REFERENCES}

[1] Abe, S. (2020). Market Trends and D2C Opportunities in the COVID-19 Landscape | The AdRoll Blog.

[2] Addo, P. C., Jiaming, F., Kulbo, N. B., \& Liangqiang, L. (2020). COVID-19: fear appeal favoring purchase behavior towards personal protective equipment. The Service Industries Journal, 40(7-8), 471-490.

[3] Ali, B. (2020). Impact of COVID-19 on consumer buying behavior toward online shopping in Iraq. Ali, BJ (2020). Impact of COVID-19 on consumer buying behavior toward online shopping in Iraq. Economic Studies Journal, 18(42), 267-280

[4] Amalia, P., Mihaela, D., \& Ionuţ, P. (2012). From Market Orientation to the Community Orientation for an Open Public
Administration: A Conceptual Framework. Procedia - Social and Behavioral Sciences, 62, 871-875.

[5] Amichai-Hamburger, Y., Wainapel, G., \& Fox, S. (2002). " On the Internet no one knows I'm an introvert": Extroversion, neuroticism, and Internet interaction. Cyberpsychology \& behavior, 5(2), 125-128.

[6] Andersen, M., Pesko, M. F., Simon, K. I., Andersen, M., \& Maclean, J. C. (2020). Effect of a federal paid sick leave mandate on working and staying at home during the COVID-19 pandemic: Evidence from cellular device data. NBER Working Paper No. 27138.

[7] Ang, S. H., Cheng, P. S., Lim, E. A. C., \& Tambyah, S. K. (2001). Spot the difference: Consumer responses towards counterfeits. Journal of Consumer Marketing, 18(3), 219233.https://doi.org/10.1108/07363760110392967

[8] Arafat, S. Y., Kar, S. K., Menon, V., Kaliamoorthy, C., Mukherjee, S., Alradie-Mohamed, A., \& Kabir, R. (2020). Panic buying: an insight from the content analysis of media reports during COVID-19 pandemic. Neurology, Psychiatry and Brain Research, 37, 100-103.

[9] Arora, N., Charm, T., Grimmelt, A., Ortega, M., Robinson, K., Sexauer, C., \& Yamakawa, N.(2020). A global view of how consumer behavior is changing amid COVID-19.McKinsey \& Company, 1-15.

[10] Asioli, D., Varela, P., Hersleth, M., Almli, V. L., Olsen, N. V., \& Naes, T. (2017). A discussion of recent methodologies for combining sensory and extrinsic product properties in consumer studies. Food Quality and Preference, 56, 266-273

[11] Bhatti, A., Akram, H., Basit, H. M., Khan, A. U., Raza, S. M., \& Naqvi, M. B. (2020). E-commerce trends during COVID-19 Pandemic. International Journal of Future Generation Communication and Networking, 13(2), 1449-1452

[12] Botti, S., \& McGill, A. L. (2011). The locus of choice: Personal causality and satisfaction with hedonic and utilitarian decisions. Journal of Consumer Research, 37(6), 1065-1078.1065-1078. https://doi.org/10.1086/656570

[13] Bounie, D., Camara, Y., \& Galbraith, J. W. (2020). Consumers' Mobility, Expenditure and Online-Offline Substitution Response to COVID-19: Evidence from French Transaction Data. Available at SSRN 3588373.

[14] Bogenberger, K., \& Weikl, S. (2012). Quality management methods for real-time traffic information. Procedia-Social and Behavioral Sciences, 54, 936-945.

[15] Durante, K. M., \& Laran, J. (2016). The effect of stress on consumer saving and spending. Journal of Marketing Research, 53(5), 814-828.

[16] Fernández-Villaverde, J., \& Jones, C. I. (2020). Estimating and Simulating a SIRD Model of COVID-19 for Many Countries, States, and Cities. National Bureau of Economic Research, 1-58.

[17] Fernando, I., Perera, J., Udawaththa, I., Rathnayake, C., \& Madushani, M. (2021). Consumer Stockpiling Behaviour within the Face of COVID-19 Pandemic: Systematic Review. Available at SSRN 3770202.

[18] Flatters, P., \& Willmott, M. (2009). Understanding the postrecession consumer. Harvard Business Review, 87(7/8), 106-112.

[19] Fong, M. W., Gao, H., Wong, J. Y., Xiao, J., Shiu, E. Y. C., Ryu, S., \& Cowling, B. J. (2020). Nonpharmaceutical measures for pandemic influenza in nonhealthcare settings-international travelrelated measures. Emerging Infectious Diseases, 26(9),2298-2299. https://doi.org/10.3201/eid2609.201990

[20] Gao, X., Shi, X., Guo, H., \& Liu, Y. (2020). To buy or not buy food online: The impact of the COVID-19 epidemic on the adoption of e-commerce in China. PloS one, 15(8), e0237900

[21] Global surveys of consumer sentiment during the coronavirus crisis | Marketing \& Sales |McKinsey \& Company. (n.d.). Retrieved June 23, 2021, from https://www.mckinsey.com/business functions/marketing-andsales/our-insights/global-s Urveys-of-consumer-sentiment-duringthe-coronavirus-crisis 
[22] Hall, M. C., Prayag, G., Fieger, P., \& Dyason, D. (2020). Beyond panic buying: consumption displacement and COVID-19. Journal of Service Management.

[23] Ho, J., Hui, D., Kim, A., \& Zhang, Y. (2020). Cautiously optimistic: Chinese consumer behavior post-COVID-19. McKinsey \& Company: Shanghai, China.

[24] Islam, T., Pitafi, A. H., Arya, V., Wang, Y., Akhtar, N., Mubarik, S., \& Xiaobei, L. (2021). Panic buying in the COVID-19 pandemic: A multi-country examination. Journal of Retailing and Consumer Services, 59, 102357

[25] Jeffrey, S. A., \& Hodge, R. (2007). Factors influencing impulse buying during an online purchase. Electronic Commerce Research, 7(3), 367-379

[26] Juranek, S., \& Zoutman, F. (2020). The effect of social distancing measures on intensive care occupancy: Evidence on COVID-19 in Scandinavia. NHH Dept. of Business and Management Science Discussion Paper, (2020/2).

[27] Kaur, P. An Insight into Online Buying Behaviour of Customers in Punjab, India during Covid-19 Pandemic.

[28] Keane, M., \& Neal, T. (2021). Consumer panic in the COVID-19 pandemic. Journal of econometrics, 220(1), 86-105.

[29] Kim, R. Y. (2020). The impact of COVID-19 on consumers: Preparing for digital sales. IEEE Engineering Management Review, 48(3), 212-218.

[30] Kuruppu, G. N., \& De Zoysa, A. (2020). COVID-19 and panic buying: an examination of the impact of behavioural biases. Available at SSRN 3596101.

[31] Lara Koslow, Jean Lee, Aparna Bharadwaj, Kanika Sanghi, and N. J. (2020). COVID-19 Consumer Sentiment Snapshot \#4 | BCG.

[32] Leung, J., Chung, J. Y. C., Tisdale, C., Chiu, V., Lim, C. C. W., \& Chan, G. (2021). Anxiety and Panic Buying Behaviour during COVID-19 Pandemic-A Qualitative Analysis of Toilet Paper Hoarding Contents on Twitter. International Journal of Environmental Research and Public Health, 18(3). https://doi.org/10.3390/ijerph18031127

[33] Ling, G.H.T., \& Ho, C.M.C. (2020). A new decade for social changes. Technium:Social Science Journal, 6(6), 6987. https://techniumscience.com/index.php/socialsciences/article/view 1332/124

[34] Loxton, M., Truskett, R., Scarf, B., Sindone, L., Baldry, G., \& Zhao, Y. (2020). Consumer behaviour during crises: preliminary research on how coronavirus has manifested consumer panic buying, herd mentality, changing discretionary spending and the role of the media in influencing behaviour. Journal of risk and financial management, 13(8), 166.

[35] Mehta, S., Saxena, T., \& Purohit, N. (2020). The new consumer behaviour paradigm amid COVID-19: Permanent or transient?. Journal of Health Management, 22(2), 291-301.

[36] Nguyen, H. V., Tran, H. X., Le Van Huy, X. N. N., Do, M. T., \& Nguyen, N. (2020). Online book shopping in Vietnam: the impact of the COVID-19 pandemic situation. Publishing Research Quarterly, 1.

[37] Ozturk, R. (2020). Health or death? The online purchase intentions of consumers during the COVID-19 pandemic. Transnational Marketing Journal (TMJ), 8(2), 219-241.

[38] OECD. (2020). Evaluating the initial impact of COVID-19 containment measures on economic activity Introduction and key messages. Tackling Coronavirus Contributing toa Global Effort, June, $1-5$.

[39] Pantano, E., Pizzi, G., Scarpi, D., \& Dennis, C. (2020). Competing during a pandemic? Retailers' ups and downs during the COVID19 outbreak. Journal of Business Research, 116, 209-213.
[40] Patel, V., Chisholm, D., Parikh, R., Charlson, F. J., Degenhardt, L., Dua, T., Ferrari, A. J., Hyman, S., Laxminarayan, R., Levin, C., Lund, C., Medina Mora, M. E., Petersen, I., Scott, J., Shidhaye, R., Vijayakumar, L., Thornicroft, G., \& Whiteford, H. (2016). Addressing the burden of mental, neurological, and substance use disorders: key messages from Disease Control Priorities, 3rd edition. The Lancet, 387(10028), 1672-1685.

[41] Perry, R. W., \& Lindell, M. K. (2003). Understanding citizen response to disasters with implications for terrorism. Journal of Contingencies and Crisis Management, 11(2), 49-60.

[42] Prentice, C., Chen, J., \& Stantic, B. (2020). Timed intervention in COVID-19 and panic buying. Journal of Retailing and Consumer Services, 57, 102203.

[43] Qiu, Y., Chen, X., \& Shi, W. (2020). Impacts of social and economic factors on the transmission of coronavirus disease 2019 (COVID-19) in China. Journal of Population Economics, 33(4), 1127-1172.

[44] Richardson, P. S., Dick, A. S., \& Jain, A. K. (1994). Extrinsic and Intrinsic Cue Effects on Perceptions of Store Brand Quality. Journal of Marketing, 58(4), 28-36. https://doi.org/10.1177/002224299405800403.

[45] Ryu, S., Gao, H., Wong, J. Y., Shiu, E. Y., Xiao, J., Fong, M. W., \& Cowling, B. J. (2020). Nonpharmaceutical measures for pandemic influenza in nonhealthcare settings - international travel-related measures. Emerging infectious diseases, 26(5), 961

[46] Safara, F. (2020). A Computational Model to Predict Consumer Behaviour During COVID-19 Pandemic. Computational Economics, 0123456789. https://doi.org/10.1007/s10614-02010069-3

[47] Stephany, F., Stoehr, N., Darius, P., Neuhäuser, L., Teutloff, O., \& Braesemann, F. (2020). The CoRisk-Index: A data-mining approach to identify industry-specific risk assessments related to COVID-19 in real-time. arXiv preprint arXiv:2003.12432.

[48] Suresh, A. S., \& Biswas, A. (2020). A study of factors of internet addiction and its impact on online compulsive buying behaviour: Indian millennial perspective. Global business review, 21(6), 1448-1465.

[49] Thakur, C., Diwekar, A., Reddy, B. J., \& Gajjala, N. (2020). A Study of the Online Impulse Buying Behaviour during COVID-19 Pandemic. International Journal of Research in Engineering, Science and Management, 3(9), 86-90

[50] Van den Poel, D., \& Buckinx, W. (2005). Predicting onlinepurchasing behaviour. European journal of operational research, 166(2), 557-575.

[51] Veeragandham, M., Patnaik, N., Tiruvaipati, R., \& Guruprasad, M. (2020). Consumer Buying Behaviour towards E-Commerce during COVID-19. International Journal of Research in Engineering, Science and Management, 3(9), 78-82.

[52] Woodward, R. (2009). The organisation for economic cooperation and development (OECD). Routledge.

[53] Yasir Arafat, S. M., Kumar Kar, S., Menon, V., Marthoenis, M., Sharma, P., Alradie-Mohamed, A., \&amp; Kabir, R. (2020). Media portrayal of panic buying: a content analysis of online news portals. Global Psychiatry,3(2), 249-254 